\title{
Tweaking or Breaking of the International Order: Kissinger, Shultz, and Transatlantic Relations, 1971-1973
}

\author{
Youn $\mathrm{Ki}$
}

This study analyzes the Nixon administration's attempts to renegotiate the terms of the postwar international order, focusing on two events: the reform of Bretton Woods and the Year of Europe initiative. Through these two initiatives, Nixon and Kissinger sought to tweak economic and military arrangements between the United States and Western Europe, ultimately aiming to preserve the U.S.-led liberal order and the Atlantic alliance. However, a series of American foreign policies facilitated the disintegration of the postwar international monetary system and heightened transatlantic tensions. Henry Kissinger failed to address a value complexity problem in his new European initiative, sending confusing signals to Europeans. Moreover, George Shultz's laissez-faire monetary policy undermined transatlantic efforts to reinstate Bretton Woods, exacerbating Europe's skepticism about U.S. intentions. Convinced that Americans were building a new political-economic system in which they would predominate, Europeans accelerated efforts to strengthen their own economic and political integration. This research emphasizes domestic sources of strain in the Atlantic alliance and the liberal international order, with further implications for post-Trump U.S. foreign policy. It highlights the importance of ideological and leadership shifts, such as the rise of neoliberalism in the 1970s and the contemporary resurgence of nationalism. Also, it cautions that strategies to preserve the status quo can be interpreted as revisionist moves due to conceptualization and coordination issues in foreign policy decision-making.

Key Words: Henry Kissinger, George Shultz, transatlantic relations, Bretton Woods, Year of Europe, foreign policy decision-making

\footnotetext{
* Youn Ki (younki1007@gmail.com) is a research professor at the Institute of International Affairs, Seoul National University. She received her PhD in political Science from the University of Chicago in 2015. She taught political science as an assistant professor at Miami University from 2015 to 2020. Her research interests include financialization, neoliberalism, and American foreign economic policy. Her articles have appeared in Enterprise \& Society, Journal of Policy History, and Research in World Economy.

*This research was supported by the Institute of International Affairs, Seoul National University.
}

The Korean Journal of International Studies Vol.19, No.1 (April 2021), 1-28 


\section{INTRODUCTION}

"America is back, the transatlantic alliance is back," President Biden declared in his speech at the annual Munich Security Conference in February 2021 (Madhani 2021). America's Western allies heaved a sigh of relief, after four years of a Trump administration which called NATO obsolete and withdrew the United States from international agreements, with the slogan of "America First." Trump's foreign policy rhetoric and practices created a sense of crisis in the liberal international order and the Atlantic alliance (Ikenberry 2018, 2019; Kaufman 2017). Commentators have emphasized that the rejuvenation of the transatlantic community is crucial for strategic as well as economic reasons in the age of America-China rivalry (Baer 2021; Karnitschnig 2021; Kraemer and Cullinane 2021). However, challenges lay ahead. The experience of the Trump presidency has pushed Europeans toward "strategic autonomy" because they found America unreliable (McTague 2021; Tharoor 2021). Moreover, nationalist resurgence in the United States seems more likely to stay, and thorny issues such as trade deals and defense burden-sharing among allies will resurface (Brands 2017).

As we look to the future, it is imperative to reflect on important moments in the transatlantic history and analyze the sources of strain in the Atlantic alliance and in the postwar liberal order. This paper examines the case of the Nixon administration, focusing on two events in the early 1970s: the reform of Bretton Woods and the Year of Europe initiative. Nixon ended gold-dollar convertibility in 1971, a central pillar of Bretton Woods, as a shock therapy to bring key allies to a monetary negotiation table. Also, Nixon and Kissinger embarked on the Year of Europe project to revitalize the Atlantic alliance, while adjusting economic and military burdens among the allies. However, transatlantic efforts to reform and reinstate the postwar Bretton Woods system fizzled in 1973, giving way to a new era of floating currencies. Moreover, the Year of Europe did not achieve any pronounced goals; instead, 1973 turned into the year of "European-American confrontation," as Nixon lamented (FRUS, Vol. E-15, Part 2, No. 28). What explains the Nixon administration's failed attempts to modify the postwar international order and intensifying transatlantic tensions?

Studies on transatlantic strains of the early 1970s have emphasized profound shifts such as the advent of détente and America's relative economic decline. Détente loosened the tie between the United States and European countries by reducing fear of the Soviet Union. Also, suspicions of separate deals with the Soviet Union fanned mistrust among the Western democracies (Hilfrich 2010: 238-89; Möckli 2010). Moreover, the waning of Pax Americana encouraged Nixon to pursue policies to renew America's economic prosperity (Sargent 2014). There 
is no doubt that these structural changes motivated the Nixon administration to refashion the Atlantic relationship and renegotiate the rules of the postwar international order. However, these environmental factors do not determine the substance and implementation of foreign policy, and, thus ultimately, interactions between different countries. This paper highlights how America's foreign policy strategies heightened transatlantic tensions by exacerbating Europe's skepticism about U.S. intentions. It builds on the literature on foreign policy decision-making which emphasizes how foreign policies are made and how these policies translate into political outcomes (Gvosdev, Blankshain, and Cooper 2019). It carefully traces U.S. decision-making process by utilizing extensive archival data from the Richard Nixon Presidential Library (Yorba Linda, CA) and the Foreign Relations of the United States series, memoirs of key policymakers such as Henry Kissinger, George Shultz, and Paul Volcker, and press reports.

This research focuses on foreign policy objectives and tactics of two top U.S. officials: Treasury Secretary George Shultz and National Security Adviser Henry Kissinger. It argues that (uncoordinated) America's foreign policy strategies facilitated a transformation of the postwar system in unexpected ways and strained the Atlantic alliance. Shultz was appointed Secretary of the Treasury by Nixon in early 1972. He represented a new breed of American leadership which sought to reorient U.S. economic policy toward laissez-faire directions. He saw the opportunity to transform the international monetary system when Nixon closed the gold window. He actively exploited and incited volatile market conditions of the time, effectively undermining transatlantic efforts to reinstate a fixed exchange rates system. ${ }^{1}$

The monetary paralysis intersected with political discord. Kissinger's Year of Europe initiative is considered as a major policy failure (Jones 2013; Möckli 2010; Noble 2010; Pietrantonio 2010; Robb 2010). Kissinger assessed the 1973 initiative in his memoir: "the year that never was" (Kissinger 1982: 192). First of all, he did not properly address what Alexander George calls "value complexity" which means "the presence of multiple, competing values and interests that are imbedded in a single issue" (George 1980: 26). George suggests three ways to manage value complexity: 1) attempting to satisfy all competing values, genuinely or in an illusory way, 2) accepting the value conflict and making a difficult choice, 3 ) avoiding the value conflict by playing down its importance.

\footnotetext{
${ }^{1}$ Research on Nixon's decision to close the gold window in 1971 is abound, yet what happened between 1971 and 1973 is less well known. Although many studies claim that the negotiation efforts were dampened due to the oil shock of late 1973, they lost momentum before the oil crisis (Ki and Jeung 2020).
} 
The Year of Europe project pursued conflicting goals of strengthening the Atlantic alliance and shifting burdens to Europeans. Kissinger chose the first strategy to manage value complexity, believing that he came up with a creative solution that eliminated tradeoffs among different values. His unwarranted confidence in the belief that he resolved the conflict and could achieve both goals prevented him from reading ominous signs in the process of policy implementation.

Indeed, Kissinger missed changes in European leaders' attitudes toward the Year of Europe. Studies on the Year of Europe have documented that Europeans, initially sympathetic to the project, turned increasingly negative due to their misgivings about U.S. intentions (Hilfrich 2010; Jones 2013; Möckli 2010; Nichter 2015; Noble 2010; Pietrantonio 2010; Robb 2010; Schwartz 2019). However, these studies fail to explain such changes in attitude. This paper fills this gap in the literature by investigating the monetary history and the Year of Europe in tandem. It demonstrates that Shultz's radical vision of floating exchange rates and relentless quest for it fueled Europe's fear that America was turning away from benevolent leadership and, instead, building a new political-economic order in which it would prevail. Shultz underestimated the fact that Bretton Woods was not just a technical tool to enhance trade and investment but a symbol of postwar multilateralism and American leadership. All in all, Kissinger's ambiguous transatlantic plans and Shultz's new monetary policy clearly favoring the United States confused and frustrated Europeans. Consequently, European leaders not only rejected the Year of Europe but also accelerated their efforts to create Europe's own monetary union and to strengthen the European Community (EC), both of which Nixon and Kissinger had long struggled to avoid.

This paper sheds light on the political consequences of the fall of Bretton Woods. While the causes of the incidence and its impacts on global finance have been extensively studied (Bordo and Eichengreen 1993; Eichengreen 2008; Gowa 1983; Helleiner 1994; Krippner 2011; Odell 1982), its implications for transatlantic alliance have received less attention. ${ }^{2}$ This paper demonstrates how America's new international monetary policy drove a wedge between Americans and Europeans, while encouraging Europeans to integrate economically and politically.

Moreover, this research delves into the causes of transatlantic troubles in the early 1970s, with further implications for post-Trump American foreign policy. Firstly, using the framework of value complexity, this paper explores the problems

\footnotetext{
${ }^{2}$ This study builds on Zimmermann's research which documents how monetary disputes between the United States and Europe facilitated the Europeanisation of French and British foreign policies in the late 1960s (Zimmermann 2003). My research applies the insight to transatlantic relations in the early 1970 .
} 
of Kissinger's Year of Europe initiative. Kissinger's poorly conceptualized transatlantic policy, combined with Shultz's radicalism, made it extremely hard for European leaders to discern America's intentions: whether it wanted to tweak the system or break it. A proper handling of value complexity and clear signaling of benevolent leadership would be essential to reduce miscommunication among the allies. Secondly, this paper shows that domestic shifts contributed to the change in the fundamental character of the international order. The Bretton Woods system embodied the principle of embedded liberalism which balanced a liberal market economy and welfare states. This study highlights how ideological and leadership shifts in the United States facilitated the evolution of the international economic regime into a neoliberal one. An interesting comparison can be made between the 1970s and the contemporary political economy. While the 1970s saw the rise of neoliberalism, now the world is facing the resurgence of nationalism. This critical shift demands more attention as we look to the future of the Atlantic alliance and the liberal world order.

\section{THE NIXON SHOCK AND THE SMITHSONIAN AGREEMENT}

On August 15, 1971, Nixon shocked the world yet again, a month after the announcement of his plan to visit China the following year. This time, he suspended gold-dollar convertibility, a crucial underpinning of the Bretton Woods monetary system, throwing the world economy into turmoil. The unilateral shock therapy was Treasury Secretary John Connally's idea to coerce Europeans into addressing unfair postwar arrangements between them and the United States. He convinced Nixon that trade barriers of foreign governments, America's military obligations overseas, and inherent flaws of the monetary system led to America's relative economic decline as well as the international monetary crisis. Nixon and Connally expected that some reworking of the international arrangements would help reinvigorate the U.S. economy and maintain the postwar world order (Nichter 2015; Sargent 2014).

Nixon's August offensive jolted Europeans and Japanese into negotiations. Connally demanded significant appreciation of major currencies, for a starter, which would boost U.S. exports and alleviate the balance of payments problem. He also pressed for trade liberalization and greater military burden sharing among allies. Determined to hold out for maximum gain, he made repeated threats that international economic uncertainty could last "indefinitely" (FRUS, Vol. 3, No. 188; Volcker and Gyohten 1992, 81-2). Europeans and Japanese leaders 
were appalled by his intransigence and brutal tactics. Some quickly introduced foreign exchange restrictions; others announced their intention to adopt retaliatory protectionist measures (FRUS, Vol. 3, Nos. 196, 197, 199). As transatlantic tensions continued to mount in the fall, other U.S. officials grew extremely nervous. Arthur Burns, Federal Reserve Chair and a Bretton Woods veteran, feared that prolonged conflicts might bring down the open economic order. He took the matter to Kissinger, warning him that the free world was on the brink of an economic war (Matusow 1998, 174; Nichter 2015, 87-9, 96).

Kissinger, who had been an outsider to the monetary affair, sensed that political costs of the economic stalemate were too grave to ignore. The United States was facing summit meetings with China and Russia in the months ahead. Kissinger was compelled to bring the Western camp in order before dealing with the adversaries (FRUS, Vol. 3, Nos. 83, 236). He convinced Nixon that the United States make concessions to end the monetary conflict, settling for less than Connally wanted (FRUS, Vol. 3, Nos. 202, 203). To resolve the monetary stalemate, Kissinger scheduled a meeting between Nixon and Pompidou, the president of France. France has been America's principal antagonist in the international monetary field, as Charles de Gaulle famously denounced the existing monetary system in the mid-1960s which allowed America to finance its debts by simply printing dollars, and asked other countries to join France in bringing the system down by converting dollars for gold. Georges Pompidou, a former Rothschild banker and protégé of de Gaulle, took a strong interest in monetary issues.

Nixon and Pompidou met in the Azores on December 13 and 14, 1971. While Nixon focused on the East-West relations during his conversations with Pompidou, Kissinger cleaned up the monetary mess. He and Pompidou agreed that America would devalue the dollar against gold, while other major countries revalued their currencies. He also accepted Pompidou's request to insert provisions in their final agreement that America would make efforts to defend the newly established exchange rates. Pompidou wanted to make sure that the United States would respect the monetary settlement. Moreover, the final agreement included provisions on the direction of international monetary reform which mirrored the French position on important issues such as fixed exchange rates, gold-dollar convertibility, and cross-border capital control. As to trade concessions and defense burden sharing, Kissinger settled for some vague language requiring negotiations "at the earliest possible date" (FRUS, Vol. 3, Nos. 219-21; Vol. 41, No. 158; Soutou 2003, 173-74).

A few days later, the Group of 10 Ministers met at the Smithsonian Institution in Washington and agreed on a currency realignment based on the result of the Nixon-Pompidou summit. The major currencies were again pegged to the U.S. 
dollar after the four-month period of floating. After all, the year 1971 did not see the end of the postwar Bretton Woods system. German Chancellor Willy Brandt celebrated the Smithsonian agreement, calling it evidence of "cohesion in the Western Alliance" (FRUS, Vol. 3, No. 221).

\section{SHULTZ AND AMERICA'S NEW INTERNATIONAL MONETARY POLICY}

George Shultz replaced Connally as Treasury Secretary in May 1972, signifying critical changes in American foreign economic policy. He was a professional economist and experienced public official. He taught at the University of Chicago, where he met Milton Friedman and became an ardent admirer. He joined the Nixon administration in 1969 as Labor Secretary; a year and a half later, he became the first director of the Office of Management and Budget. Upon his arrival at the Treasury, he embarked on the development of the U.S. position on international monetary reform. He envisaged a system of floating exchange rates determined in open markets. The system, he believed, would allow smooth and gradual changes in currency rates, eliminating currency crises. Moreover, it would resolve the payments imbalances without resorting to intrusive and inefficient government actions such as capital controls and multilateral negotiations (Wall Street Journal 72/05/17).

However, the idea of floating currencies was taboo. Most economic officials with respectable career backgrounds, such as Fed Chair Burns and Treasury Undersecretary Paul Volcker, were determined to preserve the existing monetary order which had not only supported world trade but also embodied American leadership and international cooperation. Moreover, given strong European and Japanese preference for the par-value system, any sign of American conversion to floating would provoke enormous resistance (Volcker and Gyohten 1992, 65-8). Indeed, Shultz had already tried to guide U.S. policy toward floating prior to the Smithsonian settlement in December 1971, but he was completely blocked by other officials (FRUS, Vol. 3, No. 182). While the Western world was celebrating the Smithsonian Agreement, Shultz groaned over a missed opportunity. Without Kissinger's intervention, market forces would have dominated the monetary scene, accelerating the system's progressive disintegration.

Nevertheless, Shultz saw a glimpse of hope. Although negotiations mattered in arriving at the new rates, exchange rates were already being adjusted in the 
market well before December. For him, it was the market that ultimately drove monetary shifts, rather than Connally's coercion or Kissinger's diplomacy. He concluded that he needed to form "an alliance with the market itself" to force a change in the behavior of others. Hence, a "two-track" strategy in his crusade for floating: "the one of negotiations and the other of reality" (Shultz and Dam 1998, $115-16,127)$. He believed that the efforts to amend the formal system should be accompanied by deliberate policy choices to shape the system in actual practice as close to the ideal world of floating as possible.

In other words, the "reality track" would involve laissez-faire international monetary policy. For instance, Shultz ignored Europe's desperate cry for America's help to stabilize the market in the summer of 1972, when strong speculative pressures threatened the viability of the Smithsonian exchange parities. While European leaders asked the United States to adopt a series of countermeasures to defend the parities, Shultz believed that market forces would guide the currencies to the right levels (FRUS, Vol. 3, No. 234; Wall Street Journal 72/06/26). The passivity of the Treasury soon generated anxiety within the administration. Burns turned to Kissinger again, warning him that another monetary "blow up" would jeopardize Western unity (FRUS, Vol. 3, No. 236). In mid-July, following Nixon's order, Shultz made foreign exchange interventions. Nevertheless, he did not back down entirely. He vetoed further interventions requested by the Fed. Moreover, he continued to refuse European calls for stronger controls on cross-border capital movement (FRUS, Vol. 3, No. 242; Coombs 1976, 225).

Over the summer of 1972, Shultz's "negotiation track" also began to take shape. For the United States, one of the biggest problems with the Bretton Woods monetary system was the "asymmetric" adjustment mechanism which put a disproportionate burden on deficit countries in bringing balance to international payments. Before Shultz's appointment, Treasury officials had suggested the use of a reserve indicator which tracks a country's reserve asset levels. If a country's reserve assets deviated from preset levels, an international committee would convene to address the situation. Alternatively, Shultz's reform plan, called "Plan $\mathrm{X}$," proposed an automaticindicator system which would require a country with reserve deviations to take corrective actions, circumventing international consultations (FRUS, Vol. 3, Nos. 228, 239). That is, his adjustment system would rely on the market, rather than the political process. Monetary experts could easily notice that the automatic system was tantamount to a transitional phase to a floating monetary system (Dam 1982, 223-27). Shultz's plan also built significantly greater exchange rate flexibility into the system, including wider margins within which exchange rates could fluctuate and permission of 
indefinite floating under special surveillance.

Shultz unveiled the new U.S. reform proposal at the annual International Monetary Fund (IMF) meeting in September 1972. It drew mixed reactions from the international community. On the one hand, there was a feeling of relief that the United States finally took leadership in monetary affairs, as opposed to Connally's unilateralism (FRUS, Vol. 3, No. 243). On the other hand, nearly all foreign finance ministers and central bankers, who were allergic to the idea of floating, were dismayed by the measures to enhance flexibility in the U.S. proposal. The EC, particularly France, had major problems with automaticity of the adjustment mechanism which was in stark contrast with the existing principle of national discretion (RNPL, NSC Files, Subject Files, Box 322, Memo from Hormats to Kissinger, 72/12/18; Dam 1982, 227).

\section{KISSINGER AND THE BIRTH OF THE YEAR OF EUROPE}

Meanwhile, Kissinger was also developing ideas to refashion the postwar order. In the summer and fall of 1972, he and Nixon frequently exchanged thoughts about new transatlantic relations which had been overshadowed by East-West diplomacy (Jones 2013, 86; Nichter 2015, 103; Pietrantonio 2010, 160; Schwartz 2019, 114). The Year of Europe initiative had two motivations. ${ }^{3}$ Firstly, it aimed to revitalize the Atlantic alliance in the age of détente and nuclear parity. Détente not only loosened the tie between the allies, but also fueled U.S. Congress's demands to reduce U.S. troops in Europe (Hilfrich 2010, 238-39). However, Kissinger believed that, as the Soviet Union reached nuclear parity, European defense needed to be fortified both materially and spiritually. He wanted an overhaul of the old NATO military doctrine; he also hoped to raise the sense of Western unity which had been strained since the Nixon Shock and Connally's brinkmanship (Horne 2009, 108; Kissinger 1982, 133-36; Robb 2010, 299). Secondly, Nixon and Kissinger aimed to achieve a more balanced America-Europe relationship by asking Europe to make equal contributions to the alliance. They hoped to address America's military burdens, Europe's protectionist trade policies, and the international monetary system (Kissinger 1982, 135; Robb 2010, 299, 305; Schwartz 2019, 115).

In late 1972, Kissinger launched an interdepartmental study to set out goals and strategies for the Year of Europe. He envisioned that the initiative would involve

${ }^{3}$ The initiative gained its name, the Year of Europe, after Kissinger's public speech in April 1973. 
high-level meetings, culminating with Nixon's visit to Europe and the signing of a new Atlantic Charter in the fall of 1973. While the study was under way, the idea of strategic "linkage," in which America would demand Europe's economic concessions in exchange for America's continued military commitment, gained some traction among U.S. officials (FRUS, Vol. 3, No. 106; Vol. 41, No. 84). NSC staff Helmet Sonnenfeldt, referred to as Kissinger's Kissinger, developed the idea into three different policy options in late January, 1973: 1) no linkage, 2) minimum economic concessions, and 3) maximum economic concessions (Nichter 2015, 112-13). However, the linkage strategy was highly divisive. It was a negotiating strategy used by Nixon vis-à-vis China and the Soviet Union. The question of whether the linkage strategy was appropriate and even possible toward America's closest allies generated a heated debate during the NSC Senior Review Group meeting on January 31, 1973. While economists were favorable to the strategy, others from the State and Defense Departments opposed it. Kissinger vacillated between economic benefits and security concerns.

Kissinger: We could agree to maintain certain troop levels for a certain time if they make concessions in the economic field.

Rush (State Department): That would be very dangerous.... If we try to trade off economics for security, the Europeans would turn more to the USSR.

Mr. Flanigan (Council on International Economic Policy): We may not have the option of avoiding this, if Congress and the American people felt they're being had.

Eagleburger (Defense Department): Is this a threat that we could ever perform on? If they don't perform economically, will we talk troop cuts? Kissinger: That's not the way to do it. To maintain the proper psychological climate in the US we would have to keep in mind a broader perspective than immediate economic advantage.

The meeting was adjourned without a clear strategy to achieve two conflicting goals: utilizing security leverage for economic gains and, at the same time, reinforcing the transatlantic alliance (FRUS Vol. E-15, Part 2, No. 5). ${ }^{4}$

As much as American officials were unsure about the direction of the Year of

\footnotetext{
${ }^{4}$ Similarly, Nixon also demonstrated conflicting views on U.S. policy toward Western Europe during his meeting with the Council on International Economic Policy (CIEP). On the one hand, he warned against the economists' tendency to try to extract maximum economic benefits regardless of the cost to the Atlantic alliance, commenting that "we cannot allow the umbilical cord to be cut and Europe to be nibbled away by the Soviets." On the other hand, he finished his remarks by saying that "we may also be able to get something in the economic area by using our political-security leverage" (FRUS Vol. 1, No. 120).
} 
Europe, European leaders' expectations ran the gamut. On the one hand, Europeans generally welcomed the renewed emphasis on the Atlantic alliance in U.S. foreign policy (Kissinger 1982, 130; RNPL, NSC Files, Subject Files, Box 322, Memo from Sonnenfeldt to Kissinger, 73/01/30; Nichter 2015, 107,112; Pietrantonio 2010, 161; Soutou 2003, 179). Also, French, German, and British officials supported the basic format of the initiative which would involve high-level meetings to conduct "comprehensive" negotiations, encompassing economic, political and security issues. By addressing thorny economic problems in the broader political and security context, they hoped to prevent economic frictions from jeopardizing the transatlantic alliance (RNPL, NSC Files, Subject Files, Box 322, Memo from Hormats to Kissinger, 72/12/18; New York Times 72/12/14). On the other hand, some European officials cautioned that comprehensive negotiations could be a Trojan horse for Americans to establish "maximum linkage" between different issues, wielding a heavy security lever for largest economic concessions (Nichter 2015, 108-110;.Robb 2010, 302-3) Recognizing European concerns, NSC staffs strongly recommended Kissinger to allay such suspicions about America's new policy initiative (RNPL, NSC Files, Subject Files, Box 322, Memo from Hormats to Kissinger, 72/12/18). Nevertheless, a series of U.S. actions in early 1973 fanned Europe's misgivings about the initiative.

\section{MONETARY CRISIS AND RISING TRANSATLANTIC TENSIONS}

In January 1973, foreign currency markets tumbled again. Speculators swiftly moved from the Italian lira to the Swiss franc to the U.S. dollar, putting governments in Europe and America on the defensive. German Chancellor Brandt ordered its central bank to operate heavy foreign exchange interventions, and asked Americans to do the same "in the spirit of the Smithsonian Agreement" (FRUS Vol. 31, No. 6). Within the Nixon administration, Fed chair Burns and Treasury Secretary Shultz clashed again over the U.S. response. While Burns insisted massive intervention to defend the dollar, Shultz advocated floating. After heated debates, they settled on a compromise: exchange rate realignment. Nixon rubber-stamped the economists' decisions and sequestered himself to San Clemente, hoping that the monetary problem would go away. Under Shultz's instruction, Treasury Undersecretary Volcker left for Japan and Europe to negotiate a second devaluation of the dollar, only 13 months after the Smithsonian adjustment.

Across the Atlantic Ocean, Volcker met with anxious and angry European 
leaders who had been urging Americans to defend the Smithsonian rates (FRUS Vol. 31, No. 3, 7; Volcker and Gyohten 1992, 110; Zimmermann 2010, 138-39). His session with French Finance Minister Giscard d'Estaing on February 11 was particularly contentious. D'Estaing bitterly criticized Americans for neglecting Nixon's promise to Pompidou about defending the dollar at the Azores. He also repeatedly asked whether the United States would "begin to live up to" its obligations after another realignment (FRUS Vol. 31, No. 10; Soutou 2003, 175-76). Given the firm U.S. position and lack of viable alternatives, Europeans reluctantly acquiesced to the American suggestion of devaluation. On February 12, Shultz announced new exchange rates, along with the plan to lift U.S. capital controls by the end of 1974 .

During the crisis and Volcker's European trip, the French, British, and German leaders kept close contact with each other, concluding that Americans were not committed to promoting monetary stability or preserving the existing monetary system. Instead, they strongly suspected that the United States was trying to use the currency crisis to advance its own trade and monetary agenda. Europeans had blamed Connally's "Texas approach" for America's nationalist tendency and economic belligerence in the fall of 1971 (FRUS Vol. 3, No. 243). However, by early 1973, they wondered if such an approach reflected the Nixon administration's new foreign policy priorities. Indeed, the Nixon administration's irresponsible monetary practices seemed to confirm the skepticism among European policymakers that since August 15, 1971, "the United States had been laying down the conditions under which it will defend its foreign economic interests vis-à-vis the EC" (RNPL, White House Central Files, Subject Files, International Organizations, Box 2, Memo from Sonnenfeldt to Kissinger, 73/01/31). Convinced that the United States was now less committed to the role as the leader of the free world, European leaders began serious discussions about their own monetary solutions, ultimately aiming to construct a European monetary system (FRUS, Vol. 31, No. 10; Soutou 2003, 175-76; Zimmermann 2010, 142).

The second devaluation lasted only two weeks. It destabilized the currency market, instead of stabilizing it, because it only revealed America's lack of will to defend the newly established exchange rates. Massive speculative attacks caused Europe's monetary authorities to abandon their efforts to sustain the new parities and to close exchange markets in early March. On March 3, EC leaders and European central bankers gathered to discuss a common European response to the currency crisis, possibly a joint float against the dollar. That is, European currencies would be pegged to each other, while collectively floating against the U.S. dollar (New York Times 73/03/04).

The EC meeting alarmed the Nixon administration, finally drawing Nixon's and 
Kissinger's attention to the international monetary affairs. Nixon immediately convened high-level meetings. Kissinger focused on the political implications of a common European solution. He ranted that it was unacceptable for Europeans to make a "unilateral decision" without consultations with the United States. He feared that Europe's economic integration would lead to political integration, marginalizing the role of the United States in Europe (FRUS, Vol. 31, Nos. 16, 17). Nixon and Kissinger concurred that "European unity will not be in our interest" (FRUS, Vol. E-15, Part 2, No. 9). To their horror, Germany, France, Belgium, the Netherlands, Luxembourg, and Denmark swiftly confirmed and announced the adoption of a joint float on March 11; Norway and Sweden joined the pack in a few days. They desperately looked for ways to undermine Europe's collective monetary initiative.

Shultz seized the moment. He first consoled Nixon and Kissinger with the thought that Europe's joint float was most likely to fail, and, when it did, Europeans would ask for America's leadership (FRUS, Vol. 31, Nos. 17, 24). Moreover, under Shultz's supervision, Treasury officials convinced Kissinger that the less the United State intervened in the market, the more disruptive foreign currency markets would be, thereby undermining Europe's ability to maintain a joint float. Kissinger followed their suggestions, asking them to create conditions under which the joint float was "as hard to work as possible" (FRUS, Vol. 31, Nos. 32, 33, 35). With the full support of Kissinger, Shultz firmly declined subsequent European leaders' requests to intervene in the currency markets to stabilize exchange rates.

Furthermore, Shultz explained to Europe the significance of America's monetary policy in the broader context of its new transatlantic policy, evoking Kissinger's Year of Europe. He told German Chancellor Brandt that America's non-intervention approach was not a hasty decision but a conscious policy choice to reconstruct a desirable international monetary system which fit into a broader U.S. plan to develop an "international system" encompassing trade and security areas. Brandt responded that he had supported an institutionalized forum for Europe and the United States to improve consultative dialogue between them, but recently changed his mind, now feeling "more reluctant" on the question (FRUS, Vol. 31, No. 37; RNPL, NSC Files, Subject Files, Box 322, Memo from Rogers to Nixon, 73/02/01). Furthermore, Europe's suspicion intensified, dreading that Americans would threaten to withdraw security assurance unless the EC made substantial economic concessions. European Finance Ministers and the political director of EC agreed that they would have to resist U.S. attempts to negotiate trade, money, and defense in one package (Nichter 2015, 109-110; Noble 2010, 223). 
On March 16, the United States, major European countries, and Japan announced a joint communique which officially allowed floating until satisfactory arrangements were made. Shultz had a first victory in his "two-track" quest for floating. Now with the "reality track" being successful, the next step was the completion of the "reform track." In Europe, a new monetary adventure, despite volatile financial conditions, continued in April. On April 3, the EC established the European Monetary Cooperation Fund to facilitate credit operations between member countries, to monitor monetary policies, and to oversee currency realignment. In other words, it mimicked the role of the IMF, aspiring to build the Bretton Woods system in Europe (Eichengreen, Globalizing Capital, 149-53).

\section{NIXON-POMPIDOU SUMMIT AND THE FAILURE OF THE YEAR OF EUROPE}

After the monetary discord, Kissinger was compelled to fasten the loosening transatlantic tie. He hurriedly announced his new grand agenda toward Western Europe on April 23. He pronounced that 1973 would be the "Year of Europe," with America's renewed commitment to European security and the Atlantic partnership. However, his speech was anticlimactic. It merely repeated what he had already consulted with European officials in the previous year, such as comprehensive negotiations at the highest-level. The important question of linkage remained extremely vague. Some European reporters were relieved that Kissinger's speech did not suggest a bargain between America's security guarantee and Europe's economic concessions, while others took the ambiguity as an ominous sign of maximum linkage (Pietrantonio 2010, 164; Hilfrich 2010, 241-42; Jones 2013, 95; Soutou 2003, 179-80; Kissinger 1982, 157, 161). The official European reactions were quite reserved, delaying any discussion of the substance of his proposal. As Kissinger was patiently trying to decipher the unexpected European reserve, he learned that both the British and Germans were also eager to stay in step with the French (FRUS, Vol. E-15, Part 2, Nos. 15, 18; Kissinger 1982, 154-56, 162-70; Robb 2010: 303).

Accordingly, Kissinger arranged a bilateral summit between Nixon and Pompidou at Reykjavik, Iceland, which he hoped to serve as the "key to unlock the Year of Europe" (Kissinger 1982, 163). Prior to the summit, Kissinger had exploratory meetings with Pompidou and the new French Foreign Minister Michel Jobert in mid-May. Pompidou was "obsessed" with the international 
monetary problem and wanted to have "very precise" discussions about it during the summit. Kissinger reassured him, using the Azores meeting in December 1971 as a reference point. At the Azores meeting, Kissinger stopped Connally's brinkmanship and made monetary concessions to save the transatlantic alliance. Reminding him of the Azores, Kissinger convinced Pompidou that economic and monetary questions would "find a sympathetic hearing by President Nixon" in Iceland. Pompidou gladly responded, saying "we are going to Iceland with the desire to achieve positive things" (FRUS, Vol. 31, No. 38; Soutou 2003: 180-81).

Indeed, Kissinger had genuine intentions to make a breakthrough at Reykjavik, which he believed would boost the moral unity of the West before Brezhnev's visit to Washington in June (Kissinger 1982, 170-71; Horne 2009, 116). Ironically, however, he was so preoccupied with the Brezhnev meeting that he did not pay serious attention to the preparation of the Franco-American summit (Schwartz 2019, 119). ${ }^{5}$ On May 24, only one week prior to the Reykjavik meeting, Sonnenfeldt briefed Kissinger about three different drafts of the Atlantic Declaration created by an interagency group for the Year of Europe. These drafts did not resolve the question of whether and to what degree the Nixon administration would want to utilize the linkage strategy. (RNPL, NSC Institutional Files, Meeting Files, Box H-067, Memo from Sonnenfeldt to Kissinger, 73/05/24). The next day, Kissinger met with top U.S. officials to discuss the Year of Europe and the upcoming Nixon-Pompidou summit. Kenneth Rush, Deputy Secretary of State, poignantly reminded Kissinger, "how can we state a basis for discussion with our allies if we don't have a position ourselves?” Kissinger replied, "we are having some difficulty making up our minds on some things. This can enhance our credibility when we say we want to consult with them," justifying the situation (FRUS, Vol. E-15, Part 2, No. 18). A further problem was that the senior meeting did not have any serious discussions on the monetary matters which Pompidou took very seriously. Nevertheless, Kissinger was hopeful about the summit, believing that the United States was finally on the verge of a historic transatlantic dialogue. As he later recalled: "Impelled more by righteous conviction than by cool calculation, we read the tea leaves to give us the answers we wanted" (Kissinger 1982: 172).

On the contrary, Shultz set clear goals for the Reykjavik summit and was fully prepared to stop monetary compromises. For him, the 1971 Azores meeting represented a major setback in the journey toward floating. He dreaded that Nixon and Pompidou would do the same at Reykjavik, reversing all the monetary progress made. He wrote a very thorough and forceful memo for Nixon on

\footnotetext{
${ }^{5}$ Also, closer to the Reykjavik summit, Kissinger was distracted by another round of Vietnam negotiations, and Nixon was by Watergate.
} 
monetary and trade issues before the Reykjavik summit. In the memo, he warned against an anticipated Pompidou's tactic, which would ask for specific and substantive monetary concessions in exchange for vague promises of cooperation with the Year of Europe. NSC staffers criticized the contentious tone of Shultz's memo, but agreed with the warnings (FRUS, Vol. 31, No. 39).

Nixon and Pompidou met on May 31 and June 1, 1973. On the morning of May 31, Kissinger joined Nixon and Pompidou for the general discussion of the Year of Europe, while Shultz and d'Estaing focused on the international monetary affairs in their separate meeting. Nixon proposed the Directorate of Four, a steering group representing France, Britain, Germany and the United States, as a vehicle to expedite the Year of Europe. The concept of a directorate was originally suggested by de Gaulle and had been supported by the French government. He also tried to allay the European doubts about U.S. motives, alluding to his readiness to settle on a "practical" solution on economic matters. Pompidou hesitantly said that he was willing to join the group (FRUS, Vol. E-15, Part 2, No. 20).

Pompidou reunited with his advisers for the luncheon break and learned that America's international monetary policy did not change a bit. While Nixon was paying lip service to a flexible U.S. position, Shultz firmly repeated the official U.S. proposal for monetary reform, which included controversial ideas such as reserve indicator and temporary floating, during his session with d'Estaing. D'Estaing, on the other hand, adhered to the existing French position of the reinstatement of convertibility and fixed exchange rates. Their session on the monetary and trade issues ended in a stalemate, as Shultz had envisioned (FRUS, Vol. 31, No. 40). Pompidou returned for the afternoon session with Nixon and Kissinger. Now, he changed his mind on the four-power working group, refusing to participate. He also complained bitterly about the de facto floating system inaugurated since March, stating it had been "disastrous" for Europe. Kissinger and Nixon belatedly fussed about monetary compromises but could not come up with any meaningful accommodations. They were not prepared to have that discussion (FRUS, Vol. E-15, Part 2, No. 21; Vol. 31, No. 41). The next day, Pompidou cynically concluded about the summit: "we did not try to decide anything" (FRUS, Vol. 31, No. 42). ${ }^{6}$ Indeed, in stark contrast with the Azores meeting, the American and French leaders left Reykjavik empty handed (New York Times 73/06/01; Soutou 2003, 182, 184).

\footnotetext{
${ }^{6}$ The United States made some military concessions, including U.S. assistance in weapons development and aircraft engines, to facilitate the Year of Europe (Soutou 2003, 182-86). However, that was not enough to persuade the French to join the Big Four steering group.
} 
The Reykjavik failure was quickly followed by a downward spiral in the Year of Europe initiative and transatlantic relations. The failed summit confirmed French Minister Jobert's pessimistic views about America's new transatlantic agenda. He considered the Year of Europe proposal as a many-headed hydra, designed to gain leverage over Moscow, to pressure Europe to accommodate Americans on economic issues, and to dominate international finance by flooding the world with inconvertible dollars (Kissinger 1982, 175; Soutou 2003, 179-80). After the summit, he wrote a hostile letter to Kissinger, saying that it "would be better not to undertake the steps you propose" (FRUS, Vol. E-15, Part 2, No. 23; RNPL, NSC Files, Country Files, Box 56, Memo from Sonnenfeldt to Kissinger, 73/06/04). Moreover, French leaders sabotaged Europe's prompt responses. At the EC meeting on June 5, 1973, France blocked a summit meeting between the EC and Nixon, and opposed drawing up a new Atlantic Declaration (Kissinger 1982, 181). The British, who had been keeping a low profile until the Franco-American summit, stepped up to mediate. They suggested dividing the Year of Europe into two separate negotiations, one for defense issues within the NATO and the other for political and economic issues within the EC. The suggestion elicited wide support among the Europeans, including the French, who believed that a two-pronged negotiation approach would neutralize Kissinger's linkage strategy (Nichter 2015, 132-33; Hilfrich 2010, 242).

In late June, a historic nuclear deal between the United States and the Soviet Union drove a wedge between the United States and Europe even further. Europeans were hardly consulted by the Americans in advance (Möckli 2010, 203; Soutou 2003, 188). Fearing a superpower condominium, European leaders realized that they needed to take steps to formulate a common foreign policy (FRUS, Vol. 31, No. 45; Nichter 2015, 133-34). EC foreign ministers gathered in Copenhagen on July 23. The meeting was originally planned to have discussions on the Year of Europe proposal. However, instead of the substance of the proposal, they focused on the effective ways to harmonize European reactions vis-à-vis the United States. They decided that they would first work on a statement on European identity before initiating a dialogue with the United States. Moreover, they would negotiate with the United States exclusively through the EC's Political Committee, shunning multilateral or bilateral talks with Americans (FRUS, Vol. E-15, Part 2, No. 25; Jones 2013, 83).

The Copenhagen meeting was the last straw for Kissinger. The decisions delayed transatlantic discussions on the Year of Europe for another couple more months. What enraged him more was the fact that the Europeans cut off the United States from their deliberations. He and Nixon had envisioned an intimate steering group, between the United States and its closest European allies, as a 
major vehicle for the Year of Europe consultations. Instead, Kissinger was now "confronted with a bloc" (FRUS, Vol. 31, No. 52; Hilfrich 2010, 237, 250). This was one of his worst nightmares. He supported European unity but did not want any supranational structure for Europe which could potentially ostracize the United States. Also, his grand strategy was to sustain a bipolar status quo, while preventing a transition to a multipolar system (Del Pero 2019, 12-14). Europe's behavior was completely unacceptable to him. In late July and August, Kissinger desperately tried to put the Year of Europe initiative on life support by using brute force. He thundered at the Europeans that if they did not cooperate with the initiative, Nixon would cancel his anticipated trip to Europe in the fall. He even threatened the British that their inaction could risk losing America's nuclear deterrent (FRUS, Vol. E-15, Part 2, Nos. 26-28, 31; Robb 2010, 307).

Nevertheless, it became obvious, by the fall of 1973, that the Year of Europe was over(Kissinger 1982, 191-92). Moreover, Kissinger's plan to link military, political and economic issues to raise America's leverage was effectively nullified by Europe's suggestion of two separate negotiations in NATO and the EC (Pietrantonio 2010, 166; Robb 2010, 310). In September 1973, the State Department acknowledged that bilateral discussions were the only means of achieving the linkage strategy (RNPL, NSC Files, Subject Files, Box 322, Department telegram from Greenwald, 73/09/20). As for a new Atlantic Charter, Kissinger's intimidation did prompt Europeans to participate in the drafting of it. A new Declaration of Atlantic Relations was finally accomplished in June 1974 (Robb 2010, 309-10; Soutou 2003, 189-90; RNPL, NSC Files, Subject Files, Box 322, Memos from Sonnenfeldt to Kissinger, 73/09/15, 73/09/ 17). However, by then, "it had been drained of its moral and psychological significance by a year of bickering” (Kissinger 1982, 192-93).

\section{THE FAILURE OF THE INTERNATIONAL MONETARY REFORM}

While cold-shouldering the Americans politically, Europeans pleaded for America's monetary cooperation in the summer of 1973 . Speculations against the dollar, which had subsided in the spring, resumed in mid-May and accelerated in June and July. The decline of the dollar posed grave political problems to European governments (RNPL, NSC Files, Country Files, Box 55, Memo from Sonnenfeldt to Kissinger, 73/07/30). Also, violent fluctuations in exchange rates made it extremely difficult for Europeans to maintain a joint float. European leaders felt impotent (FRUS, Vol. 31, No. 44, 45). Realizing the shortcomings of the regional solution, they renewed efforts to reform international monetary 
system and reinstate fixed exchange rates. To appeal to the Americans, the French made significant concessions to the U.S. position, including the use of reserve indicators which they had flatly opposed. France's conciliatory attitude cheered up American and other European delegates at the IMF's Committee of 20 meetings, the locus of monetary reform negotiations, in late July. Widespread search for compromises during the meetings generated a flurry of optimism that agreement on major principles could be reached at the IMF Annual Meeting in late September (de Vries 1996, 224-25; Williamson 1977, 70; Volcker and Gyohten 1992, 122; Washington Post 73/08/01). German Finance Minister Helmut Schmidt confidently spoke to the press, stating that all reform questions would be resolved in less than six months and they would have a new monetary system in 1974 (Chicago Tribune 73/07/31).

Shultz was ambivalent about the revamped reform talks. On the one hand, as he predicted in March, precarious monetary situations prodded Europeans to look for American leadership, raising America's leverage in reform negotiations. On the other hand, he was wary of the direction of the reform, i.e., a return to the par value system. For him, the summer's currency crisis did not result from the internal defects of the floating system but from deep-rooted problems such as U.S. deficits as well as political shocks such as Watergate. While carefully weighing both sides, he received an angry phone call from Kissinger. Kissinger was furious about the fact that the European "bastards" were brazenly asking for America's leadership in the monetary reform, while behaving "beastly" toward the Year of Europe. He wanted to use America's monetary engagement as a bargaining chip to coerce Europe's political cooperation. He asked Shultz to "hang tough" at the upcoming reform negotiations, reversing the reform progress of the summer. Once Shultz drives Europeans into a corner, Nixon would make monetary concessions to Europeans "if they behave elsewhere" (FRUS, Vol. 31, No. 52).

Shultz followed Kissinger's lead who was recently elevated to the position of Secretary of State (FRUS, Vol. 31, No. 57). On September 5-7, delegates gathered for final monetary negotiations prior to the important IMF Annual Meeting in two weeks in Nairobi. Hopes were high given the summer's optimism. However, Americans took a hard position, refusing to compromise even when Europeans made additional concessions. Moreover, American delegates advocated floating, frustrating other delegates and IMF officials who had assumed that the reform would adopt fixed exchange rates. The negotiations reached deadlock (New York Times 73/09/08). The ensuing Nairobi meeting produced no progress on reform, dampening prospects for agreement anytime soon. A "feeling of the futility" of the reform exercise was prevalent toward the end of 1973 (Williamson 1977, 71). 
Volcker was disappointed with the failed negotiations, yet his feelings were not shared by Shultz and other float-advocates in the Treasury Department. They were content with floating, and had "no urge to keep the negotiations alive" (Volcker and Gyohten 1992, 123).

The dissipated reform efforts in the fall of 1973 never revived in 1974, partly due to the uncertainty generated from the oil shock and inflationary pressures. Moreover, U.S. Treasury experienced leadership change in mid-1974, welcoming an influx of neoliberals who advocated floating even more vociferously than Shultz did. The French finally gave up and agreed on legalization of floating at the Rambouillet summit in November 1975. Shultz's journey to floating was finally completed as "the formal system and the system in actual practice came together" (Shultz and Dam 1998, 127).7

\section{CONCLUSION}

This study examines the disintegration of Bretton Woods and the failure of the Year of Europe in tandem, focusing on the Nixon administration's attempts to renegotiate the terms of the postwar international order. Nixon and Kissinger sought to sustain the status quo, the postwar liberal order and Pax Americana, by tweaking the system. Nixon did not intend to bring down the Bretton Woods system or abandon America's economic leadership when he closed the gold window in 1971. His unilateral action was to serve as a catalyst for monetary reform. Similarly, Kissinger hoped to strengthen the Atlantic alliance through the Year of Europe project by resolving long-due burden-sharing issues among the allies. However, what they launched as a simple negotiation tug of war vis-à-vis European allies escalated into a full-blown transatlantic conflict and led to a new international monetary order.

To explain the transformation of the monetary system and the escalation of transatlantic tensions, this paper focuses on America's foreign policy objectives and strategies. The ascendance of Shultz as a new Treasury Secretary, his ideological convictions, and his clear foreign policy goals and actions facilitated the transition to a neoliberal monetary regime. This paper also shows that Kissinger's attempt to use America's monetary collaboration as a mere bargaining chip to coax Europe's political cooperation (i.e., participation in the Year of Europe) effectively killed the reform momentum of the summer of 1973.

\footnotetext{
${ }^{7}$ Europe took its own path, creating a regional monetary system in the late 1970 and eventually achieving monetary integration.
} 
Moreover, Kissinger and Shultz contributed to the failure of the Year of Europe. Building on the literature on foreign policy making and value complexity, this paper demonstrates that Kissinger bulldozed the Year of Europe initiative without properly addressing tradeoffs between different goals. As Goldgeier aptly put, most leaders, particularly those of great powers, tend to believe that "they can have it all" when faced with difficult tradeoffs in decision-making (Goldgeier 2020: 146). Kissinger's poor conceptualization of the Year of Europe and unwarranted positive outlook about the plan prevented him from noticing warning signs in the process of implementation. My interpretation contrasts with Nichter's recent study on the Nixon administration's European policy. He claims that the failure of Year of Europe was "far more often in implementation or execution than in a fault in the original idea" (Nichter 2015:5). By contrast, this paper analyzes problems in both conceptualization and implementation of the Year of Europe, utilizing the framework of value complexity.

In addition to Kissinger's blunders, Shultz's radicalism deepened Europe's skepticism toward America's new transatlantic approach. Initially sympathetic to Year of Europe, European leaders increasingly turned negative toward the project as they suspected the Americans' intentions. They feared America was trying to break the postwar system, seeking to build a new political-economic order in which America would predominate. Shultz underestimated the fact that the postwar monetary system was a symbol of benevolent American leadership and multilateralism. Kissinger and Nixon were cognizant of the symbolism, yet neglected monetary affairs as a secondary concern. Consequently, Europeans accelerated their efforts to integrate economically and politically.

This research makes several scholarly and policy-related contributions. First, by contextualizing a monetary shift in the broader transatlantic relations, this study highlights political implications of the fall of Bretton Woods. Second, it emphasizes how American foreign policy, against the backdrop of significant structural changes, affected the Atlantic alliance and the postwar international order. Mismanagement of value conflict in policymaking and miscoordination of different policies made Europeans skeptical of Americans' motives. Finally, this study speaks to contemporary discussions on the challenges to the transatlantic community and the liberal international order.

The Atlantic alliance, a linchpin of the postwar liberal world order, has brought prosperity and stability for generations. The United States shouldered the heaviest burden in exchange for great benefits. European allies have served as reliable partners in bolstering open trade, multilateral institutions, security cooperation, and democratic values. The age of United State-China rivalry presents new opportunities and challenges to the transatlantic community. 
Shared commitment to democratic ideals as well as strategic interests will encourage America and Europe to strengthen transatlantic solidarity. However, separate economic deals with China, declining political and economic power of the West, and changing political landscapes of both the United States and Europe complicate the Atlantic relationship (McTague 2021; Von Der Burchard 2020). This study does not intend to address all potential fault lines. Instead, it focuses on how America's domestic shifts and foreign policies could influence transatlantic cohesion and the liberal world order.

This research complements recent scholarly efforts to make sense of Trump's policy and to prescribe post-Trump strategy, using the Nixon era as a reference point. Many studies have drawn parallels between the Nixon era and the Trump presidency, claiming that America's relative decline drove both Trump and Nixon administrations to adopt contentious policies to preserve its hegemonic status (Stokes and Williamson 2020; Taesuh Cha and Jungkun Seo 2018; Mastanduno 2019; Schweller 2019). In a similar vein, this study shows that structural shifts induced the Nixon administration to reconsider the terms of the postwar world order. However, structural forces did not determine the direction of foreign policy. For instance, in the 1970s, the United States chose neoliberalism over protectionism. As such, this paper stresses domestic sources of strain in the Atlantic alliance and the postwar international order.

While the 1970s saw the rise of neoliberalism, we are observing the resurgence of nationalism. Trump's 2016 election reflected, as much as emboldened, the growing nationalist tendencies. The defeat of Trump in 2020 does not equate with the defeat of nationalism in the United States. American policymakers will likely continue to face popular demands to reverse globalization and strengthen burden-sharing among the allies. Indeed, while pronouncing America's leadership and the importance of internationalism, Biden signed a "Buy American" executive order on January 25, 2021. In this context, concerns are rising regarding the implications of Biden's "foreign policy for the middle class" for America's trading partners (Donnan 2021; Ward 2021). This domestic shift may not bring about a complete systemic meltdown but could significantly influence the character of the international order.

In addition, this study emphasizes risks involved with certain foreign policy strategies. As for tweaking the international system to accommodate nationalist demands, strategies such as "pressure and reassurance" and a "madman theory" have been recently discussed (Brands 2017; Taesuh Cha and Jungkun Seo 2018, 90). The basic premise is the well-calibrated use of maximum pressure to induce sufficient burden shifting without destroying a system. Brands even argues that America may be "primed to succeed, because Trump's election has already 
delivered a massive shock to the system" (Brands 2017: 88). However, this research demonstrates a case where policy initiatives to preserve the status quo were interpreted as revisionist moves by others. Even a skillful statesman like Kissinger failed to address a value trade-off problem and coordinate various foreign policies, leading to substantial confusion and fear among Western allies. Indeed, a recent survey by the European Council of Foreign Relations shows that the Trump administration's untraditional foreign policy and brinkmanship have inflicted irreparable damage on Europeans' perception of America. Despite the election of Biden, a majority of Europeans do not believe that the United States will come back as a global leader; moreover, they are unwilling to support America in potential international disputes (Henley 2021).

The United States needs European allies more than ever in addressing critical issues such as relations with China and Russia, global environmental and health crises, and growing authoritarian tendencies around the world. To revitalize the Atlantic alliance and foster the liberal world order, it is essential to send a clear and coherent message of benevolent leadership and act on it. Also, the Biden administration will need to address the increasing nationalist fervor, persuading Americans that America has a lot to gain from internationalism and a stronger transatlantic community.

\section{REFERENCES}

\section{ARCHIVAL MATERIALS}

Richard Nixon Presidential Library (RNPL), Yorba Linda, CA USA

Foreign Relations of the United States (FRUS) 1969-1976 (https://history.state.gov/ historicaldocuments/nixon-ford)

\section{HISTORICAL NEWSPAPERS}

Anon. 1972. "What Next?: Floating of the Pound Raises Uncertainties; Is This Another Crisis? Some Say Dollar Is in Peril; Others See Bright Spots In World Monetary Scene 'I Personally Like Crises" Wall Street Journal(June 26).

Anon. 1973. "Monetary Reform Soon: Schmidt." Chicago Tribune (July 31).

Apple, R. W. Jr. 1973. "Nixon and Pompidou Fail To Resolve Major Issues: Broad Issues Unresolved U.S. and France Fail to Narrow Gaps European Unity' Stressed 2,500 March in Protest.” New York Times (June 1).

Farnsworth, Clyde H. 1973. "Common Market Weighs Joint Step In Dollar Crisis: 
No Decision in Brussels 9 Nations Expected to Agree to Link Currencies and Allow Them to Float Action Would Form Cushion Against" New York Times (March 4).

Farnsworth, Clyde H. 1973. "Deadlock Is Seen On Money Reform: Paris Conference Of High Financial Officials Fails To Resolve Differences Complete Deadlock Seen Deadlock Is Seen On Money Reform Shultz Assays Dollar." New York Times (September 8).

Janssen, Richard. 1972. "The Shultz Shift: New Boss at Treasury Likely to Stir Change But Not Right Away Switch Back to Free-Market, Classically GOP Position Is Expected Under Shultz What Is Connally Up To Now? The Shultz Shift: New Secretary Of Treasury Likely to Stir Change." Wall Street Journal (May 17).

Reston, James. 1972. "Pompidou Favors U.S.-Europe Talks: Asks Discussions at 'Highest Level' on Economic and Political Relationship Pompidou Wants to Clarify U.S.-European Relations." New York Times, (December 14).

Rowen, Hobart. 1973. "IMF Moves Toward New Money Rules: IMF Aides Hail Progress on Money Reform." The Washington Post (August 1).

\section{BOOKS AND ARTICLES}

Baer, Daniel. 2021. "With Biden, America Is Back. Europe, Are You There?" Foreign Policy (February 9). Accessed at https://foreignpolicy.com/2021/ 02/09/america-europe-biden-transatlantic-alliance/ (March 18, 2021).

Bordo, Michael D., and Barry J. Eichengreen. 1993. A Retrospective on the Bretton Woods System: Lessons for International Monetary Reform. Chicago: The University of Chicago Press.

Brands, Hal. 2017. "US Grand Strategy in an Age of Nationalism: Fortress America and Its Alternatives." Washington Quarterly 40(1):73-94.

Coombs, Charles A. 1976. The Arena of International Finance. New York: Wiley. Dam, Kenneth W. 1982. The Rules of the Game: Reform and Evolution in the International Monetary System. Chicago: University of Chicago Press.

Del Pero, Mario. 2019. "Henry Kissinger's Three Europes." Journal of Transatlantic Studies (Springer Nature) 17(1):5-21.

Donnan, Shawn. 2021. "Biden Wants a Foreign Policy That Puts Middle-Class America First." Bloomberg.Com (February 4). Accessed at https://www. bloomberg.com/news/articles/2021-02-04/biden-s-foreign-policy-focuseson-middle-class-americans (March 18, 2021).

Eichengreen, Barry J. 2008. Globalizing Capital: A History of the International Monetary System. 2nd ed. Princeton, N.J: Princeton University Press. George, Alexander L. 1980. Presidential Decisionmaking in Foreign Policy: The 
Effective Use of Information and Advice. Boulder, Colo.: Westview Press. Goldgeier, James. 2020. "NATO Enlargement and the Problem of Value Complexity." Journal of Cold War Studies 22(4):146-74.

Gowa, Joanne S. 1983. Closing the Gold Window: Domestic Politics and the End of Bretton Woods. Ithaca: Cornell University Press.

Gvosdev, Nikolas K., Jessica D. Blankshain, and David A. Cooper. 2019. Decision-Making in American Foreign Policy: Translating Theory into Practice. Cambridge: Cambridge University Press.

Helleiner, Eric. 1994. States and the Reemergence of Global Finance: From Bretton Woods to the 1990s. Ithaca, NY: Cornell University Press.

Henley, Jon. 2021. "Majority of Europeans Fear Biden Unable to Fix 'broken' US." The Guardian (January 19). Accessed at https://www.theguardian.com/ world/2021/jan/19/majority-of-europeans-say-china-will-overtake-brok en-us-within-decade (March 18, 2021).

Hilfrich, Fabian. 2010. "West Germany's Long Year of Europe: Bonn between Europe and the United States.” In M. Schulz and T. A. Schwartz ed., The strained alliance: U.S.-European relations from Nixon to Carter, Publications of the German Historical Institute, Washington, D.C.: Cambridge ; New York: German Historical Institute ; Cambridge University Press.

Horne, Alistair. 2009. Kissinger: 1973, the Crucial Year. NY: Simon \& Schuster. Ikenberry, G. John. 2018. “The End of Liberal International Order?” International Affairs 94(1):7-23.

Ikenberry, G. John. 2019. "Reflections on After Victory." The British Journal of Politics and International Relations 21(1):5-19.

Jones, Matthew. 2013. “'A Man in a Hurry': Henry Kissinger, Transatlantic Relations, and the British Origins of the Year of Europe Dispute." Diplomacy \& Statecraft 24(1):77-99.

Karnitschnig, Matthew. 2021. "Biden Takes the EU Back to the Future." POLITICO (February 18) Accessed at https://www.politico.eu/article/joebiden-europe-position-munich-security-conference-speech/ (March 18, 2021).

Kaufman, Joyce P. 2017. "The US Perspective on NATO under Trump: Lessons of the Past and Prospects for the Future." International Affairs 93(2):251-266.

$\mathrm{Ki}$, Youn, and Yongwoo Jeung. 2020. "Ideas, Interests, and the Transition to a Floating Exchange System.” Journal of Policy History 32(2):151-82.

Kissinger, Henry. 1982. Years of Upheaval. 1st ed. Boston, MA: Little, Brown and Company.

Kraemer, Richard, and Scott Cullinane. 2021. "Biden Must Get Europe Right for 
US Foreign Policy to Work for the Middle Class.” The Hill (March 17) Accessed at https://thehill.com/opinion/international/543625-bidenmust-get-europe-right-if-us-foreign-policy-is-to-work-for-the (March 18, 2021).

Krippner, Greta R. 2011. Capitalizing on Crisis: The Political Origins of the Rise of Finance. Cambridge, Mass: Harvard University Press.

Madhani, Aamer. 2021. "Biden Declares 'America Is Back' in Welcome Words to Allies.” APNEWS(February 19). Accessed at https://apnews.com/article/ biden-foreign-policy-g7-summit-munich-cc10859afd0f542fd268c0a7ddc d9bb6 (March 19, 2021).

Mastanduno, Michael. 2019. "Liberal Hegemony, International Order, and US Foreign Policy: A Reconsideration." The British Journal of Politics and International Relations 21(1):47-54.

Matusow, Allen J. 1998. Nixon's Economy: Booms, Busts, Dollars, and Votes. Lawrence, Kan: University Press of Kansas.

McTague, Tom. 2021. “Joe Biden Has a Europe Problem.” The Atlantic (January 21). Accessed at https://www.theatlantic.com/international/archive/2021/ 01/joe-biden-europe/617753/ (March 18).

Möckli, Daniel. 2010. "Asserting Europe’s Distinct Identity: The EC Nine and Kissinger's Year of Europe." In M. Schulz and T. A. Schwartz ed., The strained alliance: U.S.-European relations from Nixon to Carter, Publications of the German Historical Institute, Washington, D.C.: Cambridge ; New York: German Historical Institute; Cambridge University Press.

Nichter, Luke A. 2015. Richard Nixon and Europe. The Reshaping of the Postwar Atlantic World. Cambridge University Press.

Noble, Alastair. 2010. “Kissinger's Year of Europe, Britain's Year of Choice.” In M. Schulz and T. A. Schwartz ed., The strained alliance: U.S.-European relations from Nixon to Carter, Publications of the German Historical Institute, Washington, D.C.: Cambridge ; New York: German Historical Institute ; Cambridge University Press.

Odell, John S. 1982. U.S. International Monetary Policy: Markets, Power, and Ideas as Sources of Change. Princeton, N.J: Princeton University Press.

Pietrantonio, Silvia. 2010. "The Year That Never Was: 1973 and the Crisis between the United States and the European Community." Journal of Transatlantic Studies (Springer Nature) 8(2):158-77.

Robb, Thomas. 2010. "Henry Kissinger, Great Britain and the 'Year of Europe': The 'Tangled Skein.” Contemporary British History 24(3):297-318.

Rosato, Sebastian. 2014. "The Inscrutable Intentions of Great Powers." 
International Security 39(3):48-4.

Sargent, Daniel J. 2014. A Superpower Transformed: The Remaking of American Foreign Relations in the 1970s. Oxford University Press.

Schwartz, Thomas Alan. 2019. "A Frankenstein Monster': Henry Kissinger, Richard Nixon, and the Year of Europe." Journal of Transatlantic Studies (Springer Nature) 17(1):110-28.

Schweller, Randall L. 2019. “Organised Anarchy: Revisiting G. John Ikenberry's After Victory." The British Journal of Politics and International Relations 21(1):63-70.

Shultz, George Pratt, and Kenneth W. Dam. 1998. Economic Policy beyond the Headlines. 2nd ed. University of Chicago Press.

Soutou, Georges-Henri. 2003. "Georges Pompidou and U.S.-European Relations." In M. Trachtenberg ed., Between empire and alliance: America and Europe during the Cold War, Lanham, Md: Rowman \& Littlefield Publishers.

Stokes, Doug, and Martin Williamson. 2021. "The United States, China and the WTO after Coronavirus.” The Chinese Journal of International Politics 14(1): 23-49.

Taesuh Cha and Jungkun Seo. 2018. "Trump by Nixon: Maverick Presidents in the Years of U.S. Relative Decline." Korean Journal of Defense Analysis 30(1):79-96.

Tharoor, Ishaan. 2021. "Analysis | Biden Faces a Relieved but Cautious Europe." Washington Post (February 5). Accessed at https://www.washingtonpost. com/world/2021/02/05/biden-europe-macron-china-relationship/ (March 18, 2021).

Volcker, Paul A., and Toyoo Gyohten. 1992. Changing Fortunes: The World's Money and the Threat to American Leadership. 1st ed. New York: Times Books.

Von Der Burchard, Hans. 2020. "Merkel Pushes EU-China Investment Deal over the Finish Line despite Criticism.” POLITICO (December 29) https://www. politico.eu/article/eu-china-investment-deal-angela-merkel-pushes-finishline-despite-criticism/ (March 26, 2021).

de Vries, Margaret Garritsen. 1996. The International Monetary Fund 1972-1978: Cooperation on Trial Volume I: Narrative and Analysis. International Monetary Fund.

Ward, Alex. 2021. "Joe Biden Is Already Facing an Ally Problem.” Vox (January 26). Accessed at https://www.vox.com/22250321/biden-europe-chinavenezuela-trade (March 18, 2021).

Williamson, John. 1977. The Failure of World Monetary Reform, 1971-74. 
Sunbury-on-Thames: Nelson.

Zimmermann, Hubert. 2003. "Western Europe and the American Challenge: Conflict and Cooperation in Technology and Monetary Policy, 1965-1973." In M. Trachtenberg ed., Between empire and alliance: America and Europe during the Cold War, Lanham, Md: Rowman \& Littlefield Publishers.

Zimmermann, Hubert. 2010. "Unraveling the Ties That Really Bind: The Dissolution of the Transatlantic Monetary Order and the Creation of a European Exchange Rate Mechanism, 1965-1973.” In M. Schulz and T. A. Schwartz ed., The strained alliance: U.S.-European relations from Nixon to Carter, Publications of the German Historical Institute, Washington, D.C.: Cambridge; New York: German Historical Institute; Cambridge University Press.

[Received Jan 31, 2021; Revised Mar 30, 2021; Accepted Apr 7, 2021] 